\title{
A Method for Estimation of 3D Position and Camera Self-Calibration Using Results of Human Detection
}

\author{
Hiroaki Ando Non-member (Chubu University, ah@vision.cs.chubu.ac.jp) \\ Hironobu Fujiyoshi Member (Chubu University, hf@cs.chubu.ac.jp)
}

Keywords: camera self-calibration, pedestrian detection, segmentation, 3D position estimation

A camera self-calibration method based on the results of human detection is proposed. This method extracts the positions and heights of people in the target scene from the results of human detection and human-area segmentation, and it estimates camera parameters such as the location of the camera in the world coordinates and a vanishing line in the image coordinates.

Fig. 1 shows the relationship between the camera position and the image height of a human. The origin of the image coordinate system is assumed to be at the bottom left corner of the image, and the image coordinates are represented as $(\mathrm{u}, \mathrm{v})$. Furthermore, world coordinates are represented as $(x, y, z)$, where $\mathrm{y}$ denotes height and $\mathrm{z}$ denotes depth. We defined the camera parameters using the following notation: camera tilt, $\theta$; focal length, $f$; camera optical center, $\left(u_{c}, v_{c}\right)$; and camera height, $y_{c}$. The camera tilt is given by the following formula.

$$
\theta=2 \arctan \frac{v_{c}-v_{0}}{2 f}
$$

The world coordinate system is defined by $z_{c}=0, x_{c}=0$, and the ground plane at $y=0$. We assume zero roll and define the horizon position $\mathrm{v}$ as the vanishing line of the ground plane in the image coordinate system. The conversion from the world coordinate system to the image coordinate system is given by the following formula.

$$
\left[\begin{array}{l}
u \\
v \\
1
\end{array}\right]=\frac{1}{z}\left[\begin{array}{ccc}
f & 0 & u_{c} \\
0 & f & v_{c} \\
0 & 0 & 1
\end{array}\right]\left[\begin{array}{cccc}
1 & 0 & 0 & 0 \\
0 & \cos \theta & -\sin \theta & y_{c} \\
0 & \sin \theta & \cos \theta & 0
\end{array}\right]\left[\begin{array}{l}
x \\
y \\
z \\
1
\end{array}\right]
$$

When expression (2) is transformed and is expressed in terms of homogenous coordinates, the following equation is obtained.
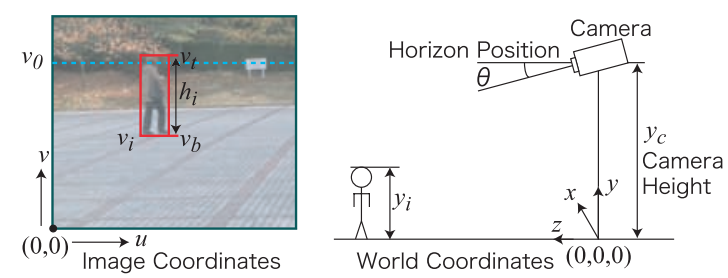

Fig. 1. Relationship between camera position and human height

$$
\left[\begin{array}{c}
v_{0} \\
y_{c}
\end{array}\right]=\left[\begin{array}{cc}
y_{i} & -h_{i} \\
\vdots & \vdots \\
y_{n} & -h_{n}
\end{array}\right]^{-1}\left[\begin{array}{c}
y_{i} v_{i} \\
\vdots \\
y_{n} v_{n}
\end{array}\right] \ldots \ldots \ldots \ldots \ldots \ldots \ldots \ldots \ldots
$$

The camera height and horizon position are obtained using equation (3). Table 1 lists the estimated values of the parameters. The experimental results show that the accuracy of the estimated camera parameters can be improved by using the results of human-area segmentation. Figs. 2 and 3 show the estimated results for 3D positions. Calibrating a camera generally requires intensive effort, but the proposed method can perform self-calibration using parameters that are automatically extracted from the target image. As a result, our method can estimate the three-dimensional position of an object even when a camera that has not been previously calibrated is used.

Table 1. Estimated values of camera parameter

\begin{tabular}{c|c|c|c}
\hline \multirow{2}{*}{ Camera parameter } & \multirow{2}{*}{ True value } & \multicolumn{2}{|c}{ Segmentation } \\
\cline { 3 - 4 } & & Proposed & Conventional \\
\hline Camera height $y_{c}$ [cm] & 184.6 & 186.7 & 205.2 \\
\hline Camera angle $\theta$ [degree] & 10.0 & 13.4 & 16.9 \\
\hline
\end{tabular}
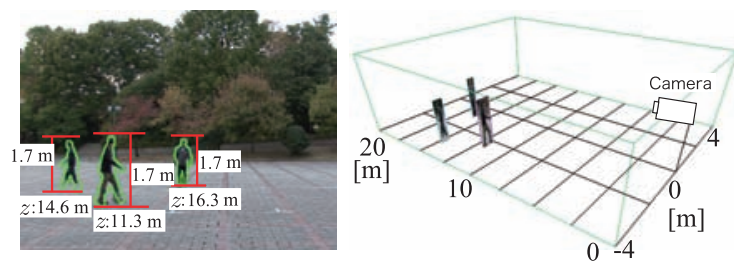

Fig. 2. Estimation result 1 (original sequence) $y_{c}=$ $168.6[\mathrm{~cm}], v_{0}=0.46, \theta=-1.6[\mathrm{deg}]$

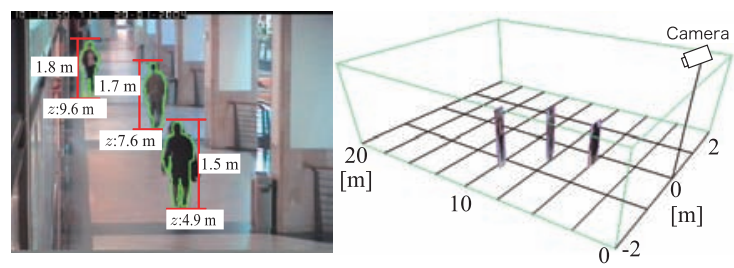

Fig. 3. Estimation result 2 (CAVIAR dataset 2) $y_{c}=$ $360.03[\mathrm{~cm}], v_{0}=1.17, \theta=27.5[\mathrm{deg}]$ 


\title{
人検出結果に基づく自己カメラキャリブレーションと 3 次元位置推定
}

\author{
非会員 安藤 寛哲* 正 員 藤吉 弘亘* \\ A Method for Estimation of 3D Position and Camera Self-Calibration \\ Using Results of Human Detection \\ Hiroaki Ando*, Non-member, Hironobu Fujiyoshi*, Member
}

\begin{abstract}
A camera self-calibration method based on the results of human detection is proposed. This method extracts the positions and heights of people in the target scene from the results of human detection and human-area segmentation, and it estimates camera parameters such as the location of the camera in the world coordinates and a vanishing line in the image coordinates. Calibrating a camera generally requires intensive effort, but the proposed method can perform self-calibration using parameters that are automatically extracted from the target image. As a result, our method can estimate the three-dimensional position of an object even when a camera that has not been previously calibrated is used. Experimental results show that the accuracy of the estimated camera parameters can be improved by using the results of human-area segmentation.
\end{abstract}

キーワード：自己カメラキャリブレーション, 人検出, セグメンテーション, 3 次元位置推定

Keywords: camera self-calibration, pedestrian detection, segmentation, 3D position estimation

\section{1. はじめに}

近年，公共施設だけではなくオフィスや一般家庭への監 視カメラの普及とともに, 物体検出や追跡などの動画像処 理技術による監視システムの需要が高まっている。特に, 映像中から人を検出 ${ }^{(1)(2)} し$, 人の 3 次元位置情報や身長を 知ることは，場所に応じた人数カウントや人流測定におい て重要である。小川らは，人の身長と位置情報の推定に， 3 次元空間の光線情報に基づく手法を提案した ${ }^{(3)}$ 。この手法 では, Tsai モデル (4) に基づきカメラキャリブレーションを 行い, カメラの内部パラメータと外部パラメータを用いて 人の位置と身長の推定を行う。キャリブレーションにより 求めたカメラパラメータを利用することで, 画像中の 2 次 元座標と世界座標における 3 次元座標の関係を求めること が可能となる。しかし，一般的にカメラキャリブレーショ ンは，画像中の座標に対応する世界座標を与える必要があ り, 広い範囲でのキャリブレーションは難しく, 正確に行 うには大変な労力が必要となる。また, カメラの外部パラ メータは内部パラメータと異なり, 設置した環境に応じて 変化する。そのため, カメラを設置する度にキャリブレー

\footnotetext{
* 中部大学大学院工学研究科

于 487-8501 春日井市松本町 1200 番地

Dept. of Computer Science, Chubu Univ.

1200, Matsumoto-cho, Kasugai 487-8501
}

ションを行い, 外部パラメータを推定する必要がある。この 問題に対して手間を必要としない自己カメラキャリブレー ションの手法も多く提案されている。Lvらは, 歩行者を 背景モデルとの差分から算出し, 歩行者の頭と足下の位置 検出し, 画像中の人の高さ世界座標と画像座標の関係を用 いて消失点と水平線を算出するカメラの自己キャリブレー ション手法を提案している(5)。しかし，Lvらの手法では, ノイズ等の影響により画像中から人の大きさを安定して取 得できないという問題がある。また, Hoiem らは, 入力画 像から物体の検出を行い, 検出結果から得られた複数の物 体高さの情報と, 入力画像における三次元の面構造と消失 点を推定して, 自己カメラキャリブレーションする手法を 提案している ${ }^{(6)}$ 。これらの物体検出に基づくカメラの自己 キャリブレーション手法では, 参照する物体の画像中にお ける高さ（例えば人の高さ）を精度良く求める必要がある。 そこで, 本稿では人領域のセグメンテーション結果に基 づくカメラの自己カメラキャリブレーション手法を提案す る。提案手法は, 推定するシーンに対し人検出と人領域の セグメンテーションを用いて画像中の人の高さを求める。 人領域のセグメンテーションにはノイズ等の影響が少ない 手法として, シルエット画像と Chamfer Matching を用い た人領域のセグメンテーション手法を用いる。人領域のセ グメンテーションにより画像から抽出した複数の人の高さ と位置情報から，透視投影モデルにおける世界座標と画像 
座標の関倸を用いてカメラの自己キャリブレーションを行 う。また，自己キャリブレーションにより推定した外部パ ラメータのカメラのチルト角とカメラの高さを用いること により, 未校正のカメラにおいても 3 次元位置の情報を推 定することができる。

\section{2. 人領域のセグメンテーション}

提案手法では, 単眼のカメラで撮影された映像から, 画 像中の物体の高さと位置, 透視投影モデルに扔ける世界座 標と画像座標の関係を用いて, カメラの自己キャリブレー ションを実現する。本手法では，画像中の物体の高さ情報 を用いてカメラパラメータを高精度に推定するため, 人領 域を正確にセグメンテーションする必要がある。

本手法では, 人領域のセグメンテーション手法に, 村井 らの提案した弱識別器の応答による類似シルエットの選択 を用いたセグメンテーション手法(れを用いる。この手法は, 人検出器の学習と学習サンプルに対応するシルエット画像 のスコアからハッシュテーブルを求めるオフライン処理と, 入力画像からラスタスキャンによる人検出を行い Chamfer Matching を用いてセグメンテーションを行うオンライン処 理から構成される。処理の流れを Fig. 1 に示し, 以下に詳 細を述べる。

$\langle\mathbf{2} \cdot \mathbf{1}\rangle$ 人検出器の構築 人検出法として HOG (Histograms of Oriented Gradients) 特徵量 ${ }^{(1)}$ を用いた Real Ad${ }^{a B o o s t}{ }^{(8)}$ による人検出器を用いる。HOG 特徵量は 1 つの 局所領域内におけるエッジ方向ごとのエッジ強度に着目し た特徴量であり, 照明変動と, 局所的な幾何学的変化に頑 健な特徵量である。人検出では, この HOG 特徵量を予め 用意した学習サンプルから算出し, Real AdaBoostにより 人検出器の構築を行う。

$\langle\mathbf{2} \cdot \mathbf{2}\rangle \quad$ シルエット画像のスコア算出入力画像から 人検出を行い, シルエット画像のマッチングを行う候補領 域を推定する。構築した検出器を用いてシルエット画像の スコアを算出する。シルエットのスコアとは, 人検出器の 各弱識別器の応答值を多次元のベクトルとして表現したも のである。まず，学習サンプルからシルエット画像を作成 する。次に，作成したシルエット画像に対応する学習サン プル（ポジティブのみ）を構築した人検出器に入力する。入 力画像に対して各弱識別器は人か人以外を識別した結果と して返す。 $T$ 個の弱識別器に対応した $T$ 次元の特徵べクト ルを対応するシルエット画像のスコアとする。

〈2·3〉 ハッシュテーブルの作成＼cjkstart算出したシルエット 画像のスコアは, Chamfer Matching を行う対象領域に類似 したシルエットを選択するために使用する。シルエット画 像のスコアを記録したハッシュテーブルを作成することで 高速な類似シルエット画像検索を実現する。ある一つのシ ルエット画像 $y$ から算出された弱識別器の応答に基づくス コアを, $T$ 次元の特徵ベクトル $\mathbf{y}=\left\{h_{1}(y), h_{2}(y), \cdots, h_{T}(y)\right\}$ とする。まず, 次式により各次元の特徵量を 2 值化し, ビッ トベクトル $\mathbf{u}=\left(u_{1}, u_{2}, \cdots, u_{T}\right)$ を作成する。

$$
u_{j}=\left\{\begin{array}{l}
1 \text { if } h_{j}(y) \geq 0 \\
0 \text { otherwise }
\end{array}\right.
$$

次に, 以下の式を用いて, ハッシュテーブルのインデック ス $H_{\text {index }}$ を求め, ハッシュテーブルに特徴ベクトルとシル エット画像の ID を登録する。

$$
H_{\text {index }}=\left(\sum_{i=1}^{T} u_{i} i^{i}\right) \bmod H_{\text {size }}
$$

ここで, $H_{\text {size }}$ はハッシュテーブルのサイズである。また, 同 じインデックス $H_{\text {index }}$ が求められた場合, 一つのインデッ クスに複数のシルエット画像を対応させる。以上の処理を すべてのシルエット画像に対して行い, ハッシュテーブル を作成する。

〈2・4 類似シルエットの選択 オンライン処理とし て実際の入力画像から人検出を行い, MeanShift クラスタリ ングによりウインドウを統合する。検出されたウインドウ 内の領域が検出器に入力されたときの各弱識別器の応答値 の $T$ 次元の特徵ベクトルとシルエット画像のスコアとして 記録した特徵べクトルを比較することで類似シルエット画 像の選択を行う。その方法として, 作成したハッシュテー ブルを用いて近似最近傍探索を行う。人検出により検出さ れた領域から得られた弱識別器の応答に基づく特徵べクト ルを $\mathbf{x}=\left(h_{1}(x), h_{2}(x), \cdots, h_{T}(x)\right)$ とする。この特徴べクト ルに対しても (1), (2) 式を用いてハッシュのインデックス を求め, 同じハッシュのインデックスを持つ特徴ベクトル をハッシュテーブルから探索することで類似する特徵ベク トルを持つシルエット画像を選択する。

〈2.5〉 Chamfer Matching によるセグメンテーション 人検出により検出された領域と, 弱識別器の応答值から 選択された類似シルエット画像を Chamfer Matching ${ }^{(9)} に$ よりマッチングすることで人領域のセグメンテーションを 行う。Chamfer Matching はテンプレートマッチングの一種 であり, 入力画像とテンプレート画像間のエッジの相違度 に基づいてマッチングを行う手法である(9)。一般的なテン プレートマッチングが画像の色や輝度情報を用いるのに対 し, Chamfer Matching ではエッジのような形状情報に基づ いたテンプレートマッチングが可能である。人検出により 検出された領域を入力画像とし, 入力画像からエッジ特徽 を抽出したエッジ画像を生成する。次に, 生成したエッジ 画像に距離変換処理を行い距離変換画像を得る。距離变換 処理とは, エッジ画像に扔いて各画素から最も近いエッジ 点までの距離をその画素の輝度值として与える処理である。 このようにして生成された入力画像の距離変換画像と, テ ンプレート画像としてシルエット画像から生成したエッジ 画像を相違度に基づいてマッチングを行う。このとき，人 検出により検出された領域は必ずしもきれいに人領域を検 出しているとは限らないため, Chamfer Matching を行う領 域としてマージンを持たせて少し大きめに切り出した領域 を使用する。また, Chamfer Matching はスケール変化に敏 


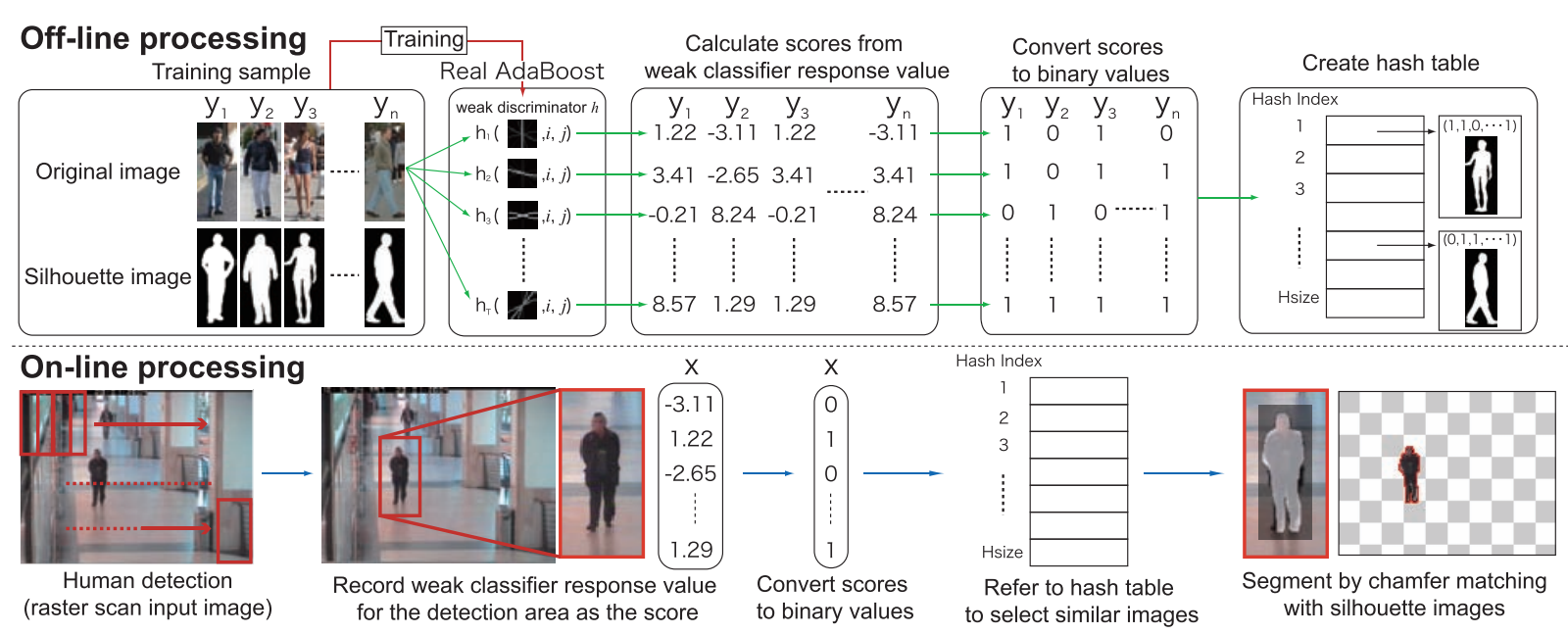

Fig. 1. Processing flow in the human-area segmentation
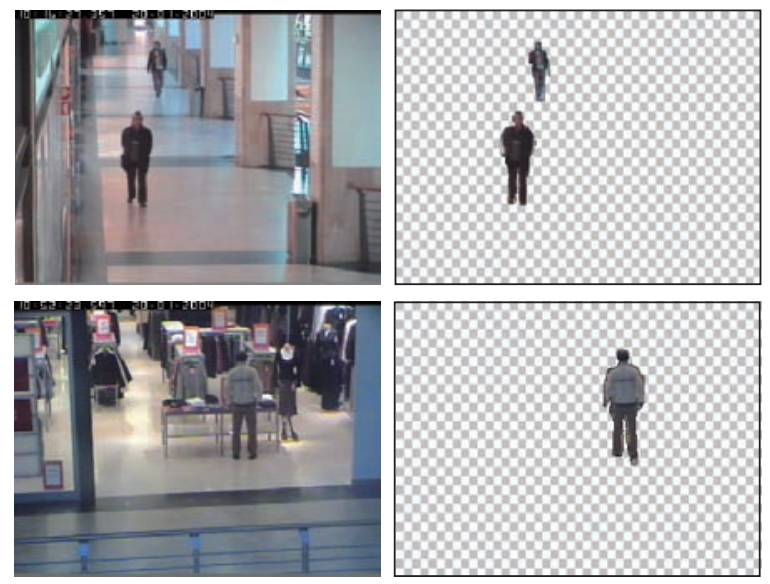

Fig. 2. Examples of human-area segmentation

感であるため，シルエット画像のスケールを変化させなが らマッチングを行う。最終的に, 最も Chamfer Matching の 相違度が小さくなる位置とスケールとシルエット画像を決 定し, シルエット画像が重なっている部分を切り出すこと で人領域のセグメンテーションを行う。Fig. 2 に Chamfer Matching を用いた人領域のセグメンテーション結果例を示 す。セグメンテーション結果から, 画像中の人の高さ $h_{i}$ と 位置 $v_{i}$ を精度よく抽出することができる。

\section{3. カメラの自己キャリブレーション}

人領域のセグメンテーション結果から得られた画像中の 人の高さを用いてカメラの自己キャリブレーションを行う。 まず，文献(6)を参考に，透視投影モデルにおけるカメラ位 置と人の高さと人の位置の関係を定式化する。本章では, 画像座標と世界座標とカメラパラメータの関係と, その関 係からカメラパラメータの導出方法について述べる。

〈3.1〉 カメラ位置と人の高さの関係 Fig. 3 に，カメ ラ位置と人の高さの関係を示す。画像の左下の座標を $(0,0)$ とし，画像の縦と横を画像の縦幅のサイズで正規化した画 像の座標系を $(u, v)$ で与える。また，世界座標系を $(x, y, z)$
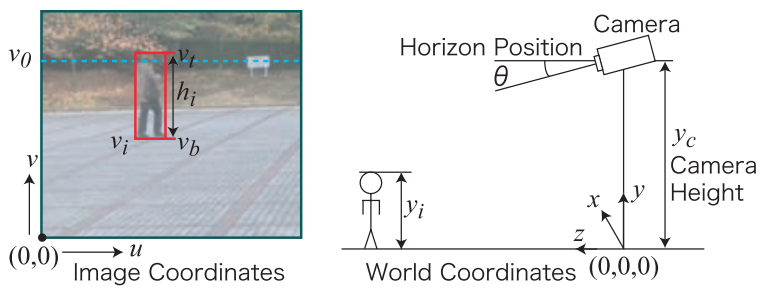

Fig. 3. Relationship between camera and human height

とする。ただし $y$ を高さ， $z$ を奥行きとする。次に，カメ ラのチルト角を $\theta$, 焦点距離を $f$, カメラ中心 $\left(u_{c}, v_{c}\right)$, カ メラの高さを $y_{c}$ とする。世界座標系は, カメラ位置を基準 として, $z_{c}=0, x_{c}=0$ とし, 接地平面を $y=0$ と定義す る。また，自己キャリブレーションにより推定した外部パ ラメータのカメラのチルト角とカメラの高さを用いること により,未校正のカメラに扔いても 3 次元位置の情報を推 定することができる。また, カメラ中心 $\left(u_{c}, v_{c}\right)$ は画像中 心とし, 焦点距離 $f$ は画像の縦幅を 1.0 で正規化して内部 パラメータのキャリブレーションした值を用いる。本論文 では $f=1.4$ を用いて実験を行う。カメラにロールは発生 せず，画像座標系の地面の消失ラインとして水平線を $v_{0}$ と 定義する。このとき，カメラのチルト角（ラジアン）は次 式で与えられる。

$$
\theta=2 \arctan \frac{v_{c}-v_{0}}{2 f} .
$$

カメラモデルとして, 歪み無しの単位アスペクト比である 透視投影モデル (Perspective projection model) を使用する と, 世界座標系から画像座標系への変換は以下の式で与え られる。

$$
\left[\begin{array}{l}
u \\
v \\
1
\end{array}\right]=\frac{1}{z}\left[\begin{array}{ccc}
f & 0 & u_{c} \\
0 & f & v_{c} \\
0 & 0 & 1
\end{array}\right]\left[\begin{array}{cccc}
1 & 0 & 0 & 0 \\
0 & \cos \theta & -\sin \theta & y_{c} \\
0 & \sin \theta & \cos \theta & 0
\end{array}\right]\left[\begin{array}{l}
x \\
y \\
z \\
1
\end{array}\right]
$$


$\langle\mathbf{3} \cdot 2\rangle$ カメラパラメータの導出 世界座標系と画像 座標系とカメラパラメータの関係から, カメラパラメータ の導出方法について説明する。(4) 式を物体の高さ $y$ につ いて解くと次式となる。

$$
y=\frac{z\left(f \sin \theta-\left(v_{c}-v\right) \cos \theta\right)-f y_{c}}{\left(v_{c}-v\right) \sin \theta+f \cos \theta} \ldots \ldots \ldots \ldots
$$

ここで，画像中の人（直立と仮定）領域の上底と下底の位 置をそれぞれ $v_{t}$ と $v_{b}$ として与える (Fig. 3)。下底位置 $v_{b}$ で地面と接する。つまり $v_{b}$ のとき $y=0$ なので, 物体の奥 行き $z$ は次式のように求められる。

$$
z=\frac{f y_{c}}{f \sin \theta-\left(v_{c}-v_{b}\right) \cos \theta} \cdots
$$

(5) 式と (6) 式から, 物体の高さ $y$ は次式のようになる。

$$
y=\frac{f y_{c}\left(f \sin \theta-\left(v_{c}-v_{t}\right) \cos \theta\right) /\left(f \sin \theta-\left(v_{c}-v_{b}\right) \cos \theta\right)-f y_{c}}{\left(v_{c}-v_{t}\right) \sin \theta+f \cos \theta}
$$

ここで, カメラのチルト角が小さい（推定された水平線の位 置が画像内に存在する) 場合, $\cos \theta \approx 1, \sin \theta \approx \theta, \theta \approx \frac{v_{c}-v_{0}}{f}$ と近似できる。従って，(7) 式は以下のように表現できる。

$$
y \approx y_{c} \frac{v_{t}-v_{b}}{v_{0}-v_{b}} /\left(1+\left(v_{c}-v_{0}\right)\left(v_{c}-v_{t}\right) / f^{2}\right) \ldots
$$

分母の $\left(v_{c}-v_{0}\right)\left(v_{c}-v_{t}\right) / f^{2}$ は, チルト角が小さいとき $v_{c}-v_{0} \approx 0$ となるため, $\left(v_{c}-v_{0}\right)\left(v_{c}-v_{t}\right) / f^{2} \approx 0$ と近似 できる。従って，(8) 式は以下のようになる。

$$
y \approx y_{c} \frac{v_{t}-v_{b}}{v_{0}-v_{b}} \text {. }
$$

ここで, 画像中に存在する $i$ 番目の人領域を考えたとき, $v_{t}-v_{b}$ は画像中の $i$ 番目の人領域の高さ $h_{i}$ とする。また, 人 領域の基準座標を矩形領域の左下に設定したとき, $v_{b}=v_{i}$ となる。従って, 求めたい式は以下のようになる。

$$
y_{i} \approx y_{c} \frac{h_{i}}{v_{0}-v_{i}} .
$$

(10) 式を変形し,$n$ 人のサンプルとの関係を行列で表現す ると次式のようになる。

$$
\left[\begin{array}{c}
v_{0} \\
y_{c}
\end{array}\right]=\left[\begin{array}{cc}
y_{i} & -h_{i} \\
\vdots & \vdots \\
y_{n} & -h_{n}
\end{array}\right]^{-1}\left[\begin{array}{c}
y_{i} v_{i} \\
\vdots \\
y_{n} v_{n}
\end{array}\right] \ldots \ldots \ldots \ldots \ldots(11)
$$

(11) 式からカメラの高さ $y_{c}$ と水平線の位置 $v_{0}$ を求める。

〈3·3〉 RANSAC によるカメラパラメータ推定

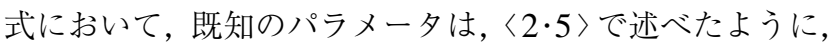
人領域のセグメンテーション結果より画像中から抽出した 人の高さ $h_{i}$ と人領域の位置 $v_{i}$ である。世界座標における カメラの高さ $y_{c}$ と画像座標上の水平線の位置 $v_{0}$ を求める ためには，世界座標系での人の高さ $y_{i}$ が必要である。しか し，与えられている映像からそれぞれの世界座標系の人の 高さの真值を知ることは不可能である。そこで, 提案手法
では人の身長として文部科学省の平成 20 年度体力・運動 能力調査の調査結果 ${ }^{(10)}$ の男性 20-59 歳の身長測定の結果 を用いて, 平均值 $170.5[\mathrm{~cm}]$, 標準偏差 5.3 の正規乱数によ り世界座標の身長を仮定する。正規乱数により仮定された 世界座標の高さ, セグメンテーション結果より画像中から 抽出した人の高さ $h_{i}$ と人領域の位置 $v_{i}$ を持つサンプルと, RANSAC (RANdam SAmple Consensus) (11)を用いてカメ ラの高さとチルト角の推定を行う。RANSAC の流れは以 下の通りである。

Step1 ランダムに2 点のサンプルを選択

Step2 最小二乗法によりカメラの高さと水平線位置を推定 Step3 推定值から全サンプルとの誤差を算出

Step4 誤差の中間值を選択

Step5 Step1 Step4 を繰り返し, 誤差の中間值が最小と なるパラメー夕を求め, 最終的なカメラの高さと水平線 位置とする

〈3.4〉人の 3 次元位置推定 推定したカメラパラメー 夕と画像中における物体の位置 $(u, v)$ から, 世界座標にお ける物体の 3 次元位置 $(x, y, z)$ を推定する。物体の奥行き $z$ は, 世界座標系と画像座標系の変換式から, $y=0$ のとき 求めたカメラパラメータのカメラの高さと, 画像座標にお ける位置関係から次式となる。

$$
z=\frac{f y_{c}}{f \sin \theta-\left(v_{c}-v_{b}\right) \cos \theta}
$$

次に, (12) 式から求めた奥行き $z$ と画像中の位置から, $x$ と $y$ を求めることが出来る。世界座標における高さ $y$ は, 奥 行き $z$ と, カメラの高さ $y_{c}$ と画像中での高さの関係から次 式となる。

$$
y=\frac{z\left(f \sin \theta-\left(v_{c}-v\right) \cos \theta\right)-f y_{c}}{\left(v_{c}-v\right) \sin \theta+f \cos \theta} .
$$

世界座標における $x$ の推定には, 世界座標系から画像座 標系に変換する (4) 式を画像座標 $u$ について解くと次式と なる。

$$
u=\frac{f x+u_{c}(y \sin \theta+z \cos \theta)}{z} .
$$

(14) 式から $x$ は次式のようになる。

$$
x=\frac{z\left(u+u_{c} \cos \theta\right)-u_{c} y \sin \theta}{f} .
$$

(15) 式から求めた世界座標における $x$ 座標と, (13) 式と (12) 式から求まる $y, z$ 座標の值を, 自己カメラキャリブ レーションで求めたカメラパラメータを用いて算出するこ とで, 対象物体の 3 次元位置を推定することができる。

\section{4. シミュレーションによる評価実験}

提案手法は, カメラチルト角が小さいと仮定しているた め, チルト角の影響を受ける。また，世界座標における人の 高さを成人男性の分布を用いて仮定したサンプルによりカ メラパラメータを推定するため, 乱数による推定誤差や推定 


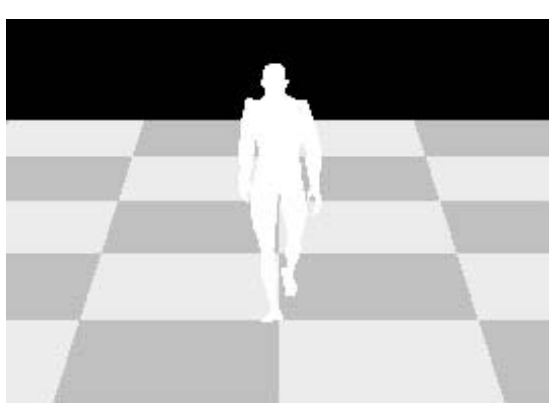

Fig. 4. Example of simulation model

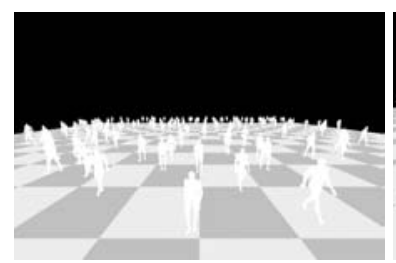

(a) $\theta=10$

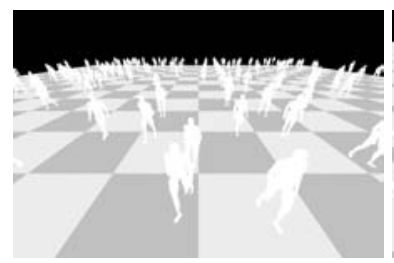

(c) $\theta=30$

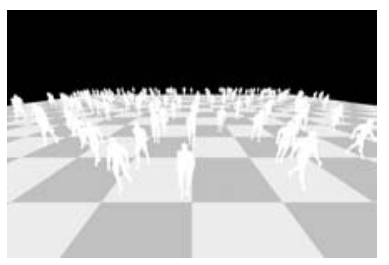

(b) $\theta=20$

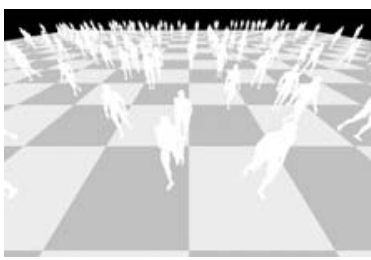

(d) $\theta=40$
Fig. 5. Example of generation sample 1

するシーンのサンプルの分布（世界座標における人の身長） の影響も受ける。そこで，提案手法に扮けるチルト角やサ ンプルの分布影響をシミュレーション実験により評価する。 実験にはFig. 4 に示すように人体シルエットを OpenGL で 描画したシミュレーションモデルを用いる。このモデルは, カメラの位置や高さ等のカメラパラメータと，人の身長や 位置等の人モデルのパラメータを変更することで様々な撮 影環境が表現可能である。

〈4・1〉 チルト角による推定精度の比較実験 提案手 法は，推定するシーンにおけるカメラチルト角に精度が影 響することが考えられる。そこで，カメラのチルト角に対 するパラメータの推定精度を調査する。シミュレーション モデルを用いてカメラチルト角 $\theta$ を 0 度 40 度まで 5 度刻 みで変化させた時のカメラパラメー夕推定精度を比較する。 ここでカメラの高さ $y_{c}$ は $3 \mathrm{~m}$, 人の位置 $(x, z)$ は乱数によっ て決定し，人の身長は文献 ${ }^{(10)}$ の成人男性の結果に従った正 規乱数により与えてサンプルを生成する。各角度でカメラ パラメータ推定に用いた人モデルのサンプル数は 600 であ る。Fig. 5 にシミュレーションモデルにより生成したサン プルの例を示す。実験の結果を Fig. 6 に示す。Fig. 6 より, チルト角が 40 度のとき推定誤差は約 11.0 [degree] となっ た。推定するシーンのチルト角が大きくなるにつれ推定誤 差が増加することが分かる。これは，カメラパラメータの 導出の過程でカメラのチルト角が小さいと仮定しているた め，チルト角が大きくなるほど推定する際に誤差が生じる

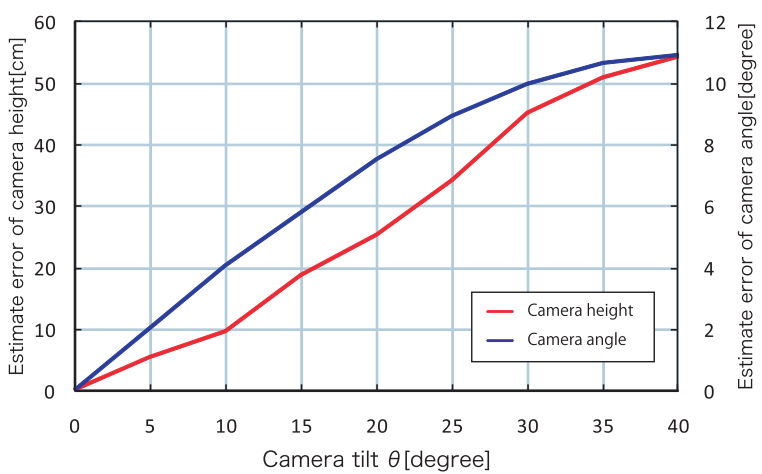

Fig. 6. Comparison of the presumed error by camera tilt
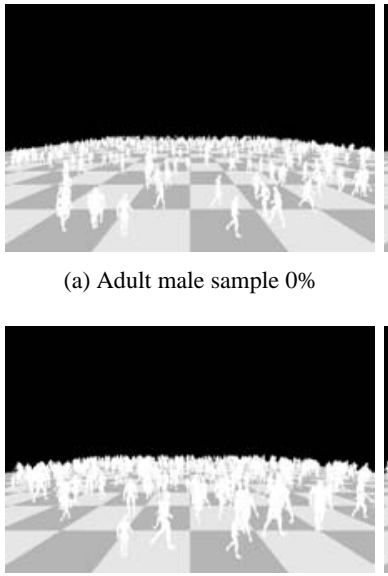

(c) Adult male sample $60 \%$ (a) Adult male sample $0 \%$

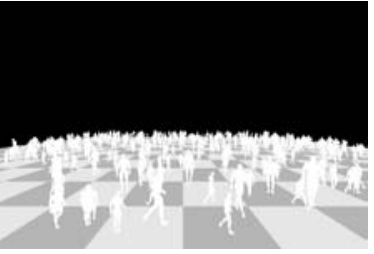

(b) Adult male sample $30 \%$

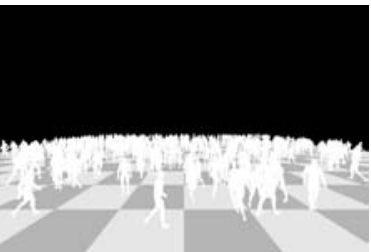

(d) Adult male sample $100 \%$
Fig. 7. Example of generation sample 2

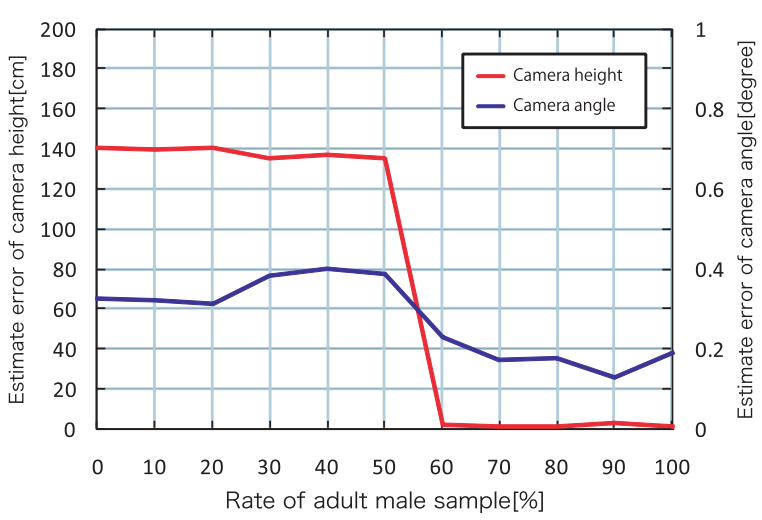

Fig. 8. Comparison of the presumed error by sample distribution

\section{と考えられる。}

〈4・2〉 サンプルの分布による推定精度の比較実験 提 案手法で用いる人の身長の分布とサンプルの分布の違いによ るカメラパラメータの推定精度を比較する。実験では提案手 法の人モデルと同様に, 人の身長としての平均值 $171.9[\mathrm{~cm}]$, 標準偏差 5.9 の正規乱数によって高さを与えて生成したサ ンプルと文献 ${ }^{(10)}$ 中の男子 6 歳の身長測定の結果である平均 身長 116.7 [cm], 標準偏差 4.8 の正規乱数によって高さを与 えて生成した子供のサンプルを用いる。サンプルを生成し たシミュレーションモデルの環境はカメラの高さ $y_{c}$ を $3 \mathrm{~m}$, 
人の位置 $(x, z)$ を乱数によって決定する。また，カメラのチ ルト角は推定結果に含まれる誤差を抑えるため 0 度でサン プルを生成した。Fig.7 にシミュレーションモデルにより 生成したサンプルの例を示す。実験ではカメラパラメータ 推定に用いる人のサンプル数を 1000 とし, 成人男性の人体 モデルで生成したサンプルと子供のモデルにより生成した サンプルの割合を変化させ精度を比較する。サンプルの割 合は成人男性の人モデルが $0 \%$ 100\%まで $10 \%$ 毎変化させ る。実験結果を Fig. 8 に示す。提案手法では, RANSACを 用いて全サンプルからカメラパラメータ推定に最適なサン プルの組み合わせを選択して推定するため，成人男性の人 モデルに当てはまらない身長のサンプル（子供のサンプル 等) がノイズとして含まれているシーンに対しても，仮定 した成人男性のモデルが $60 \%$ 以上含まれる場合, RANSAC により高精度にカメラの高さを推定できる。

\section{5. 実画像による評価実験}

提案手法の有効性を確認するために, 実画像におけるカメ ラパラメータの推定と 3 次元位置の推定の評価実験をする。

〈5・1〉 カメラパラメータの推定撮影した映像から人 領域のセグメンテーションを行い，その結果から撮影した カメラの自己キャリブレーションを行う。求めるパラメー 夕はカメラの高さ $y_{c}$ と水平線位置 $v_{0}$ で, 水平線位置 $v_{0}$ と (3) 式からカメラの角度 $\theta$ である。また, 推定したパラメー 夕を用いて現実世界での 3 次元位置の推定を行う。推定に 用いるオリジナルデータセットは $640 \times 360$ ピクセル，セグ メンテーション結果のサンプル数は 600 である。Fig. 9(a), (b) にカメラパラメータの推定に用いた 600 サンプルの人

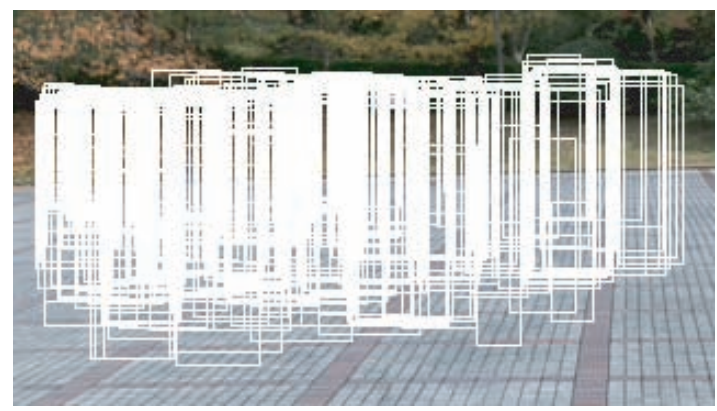

(a) With Segmentation

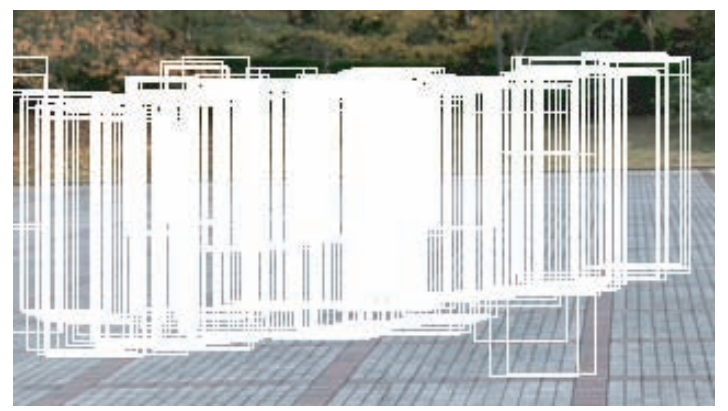

(b) Without Segmentation

Fig. 9. Distribution of detection
検出結果の分布を示す。Table 1 にパラメータ推定結果を 示す。Table 1 より，セグメンテーションありの場合にカ メラ高さが真值との誤差が約 $2.1[\mathrm{~cm}]$, カメラの角度が真 值との誤差は約 3.4 [degree] の精度で推定できた。Fig. 10, Fig. 11 に自己キャリブレーションにより推定した水平線位 置 $v_{0}$, カメラの高さ $y_{c}$ と (10) 式から推定した検出した人 の身長，チルト角 $\theta$ と (12) 式から求めた奥行き $z$ の值を示 す。提案するカメラの自己キャリブレーション法は, カメ ラの内部パラメータを推定することはできないが, 推定し たカメラの高さ $y_{c}$ と水平線位置 $v_{0}$ を用いることで人検出 の誤検出抑制やトラッキング精度の向上が期待できる。

$\langle\mathbf{5 \cdot 2 \rangle}$ 人の 3 次元位置の推定推定したカメラパラ メー夕を用いて，検出した人の世界座標における 3 次元位 置を推定をする。Fig. 12 に示す 15 点のランドマーク点の 画像座標を用いて世界座標の真值と推定結果比較すること で, セグメンテーションによる精度比較と, 実際にシーン における 3 次元位置の精度評価を行う。Fig. 13 に 3 次元位 置の推定結果を示す。また, Table 2 に 3 次元位置推定誤差 の $x$ 軸, $z$ 軸の平均と分散を示す。セグメンテーションし

Table 1. Estimation results of camera parameter

\begin{tabular}{c|c|c|c}
\hline \multirow{2}{*}{ Camera parameter } & \multirow{2}{*}{ True value } & \multicolumn{2}{|c}{ Segmentation } \\
\cline { 3 - 4 } & & Proposed & Conventional \\
\hline Camera height $y_{c}[\mathrm{~cm}]$ & 184.6 & 186.7 & 205.2 \\
\hline Camera angle $\theta[$ degree] & 10.0 & 13.4 & 16.9 \\
\hline
\end{tabular}

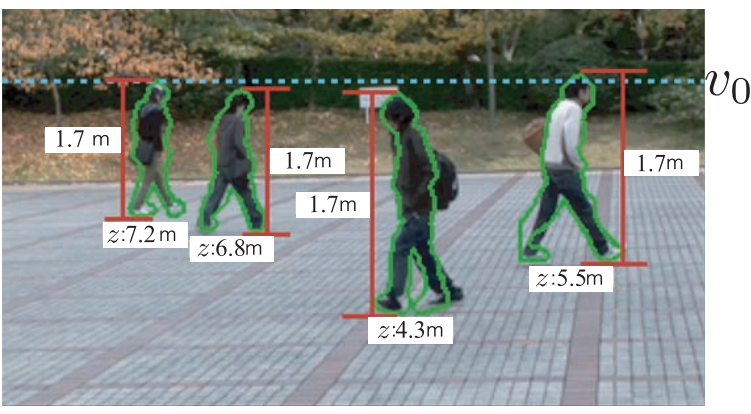

Fig. 10. Estimation result 1 (Original Sequence) $y_{c}=$ $186.7[\mathrm{~cm}], v_{0}=0.828, \theta=13.4[\mathrm{deg}]$

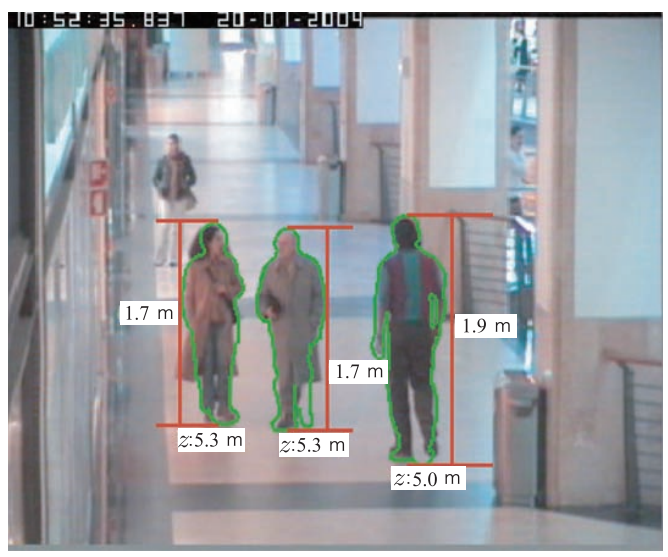

Fig. 11. Estimation result 2 (CAVIAR dataset 2) $y_{c}=$ $360.03[\mathrm{~cm}], v_{0}=1.17, \theta=27.5[\mathrm{deg}]$ 


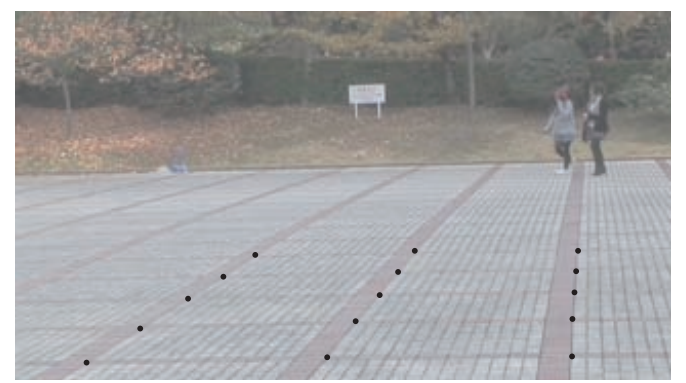

Fig. 12. Estimation for 3D positions (Original Sequence)

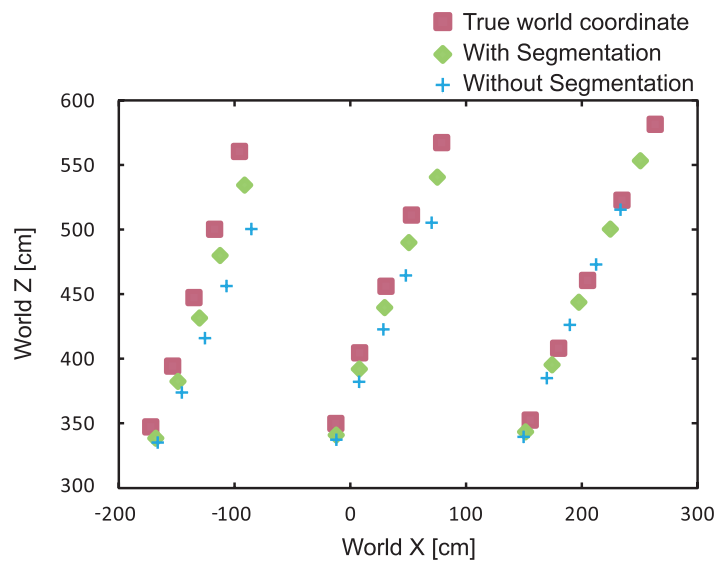

Fig. 13. Estimation error of 3D positions (Original Sequence)
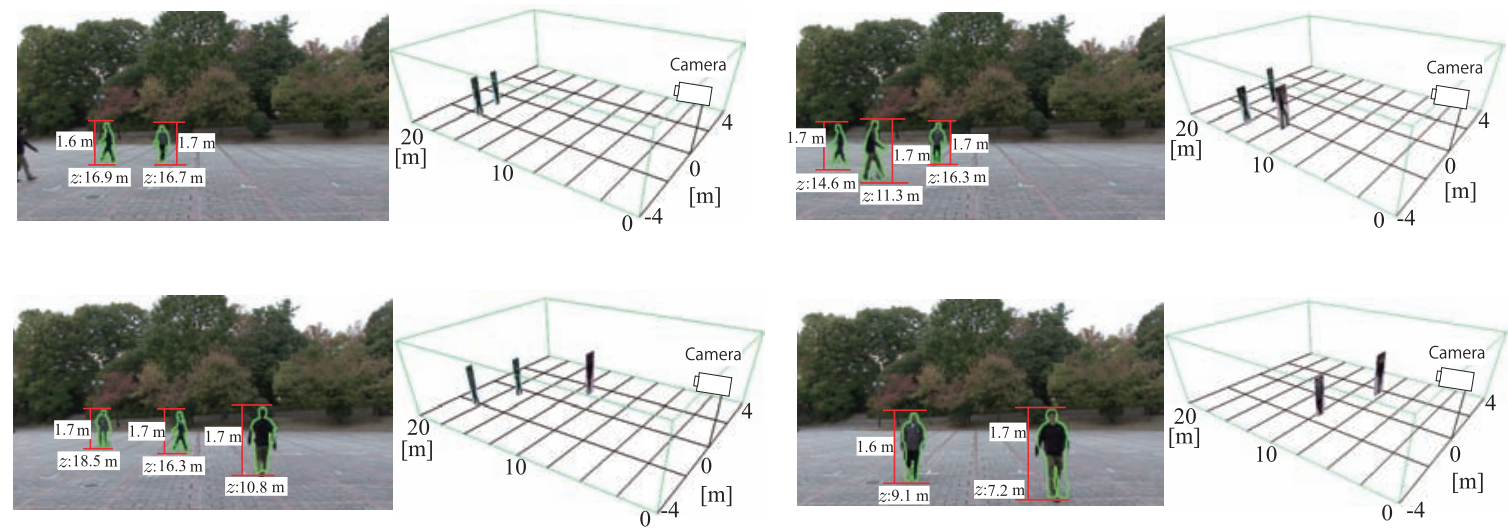

Fig. 14. Estimated results of 3D positions 1 (Original Sequence) $y_{c}=168.6[\mathrm{~cm}], v_{0}=0.46, \theta=-1.6[\mathrm{deg}]$
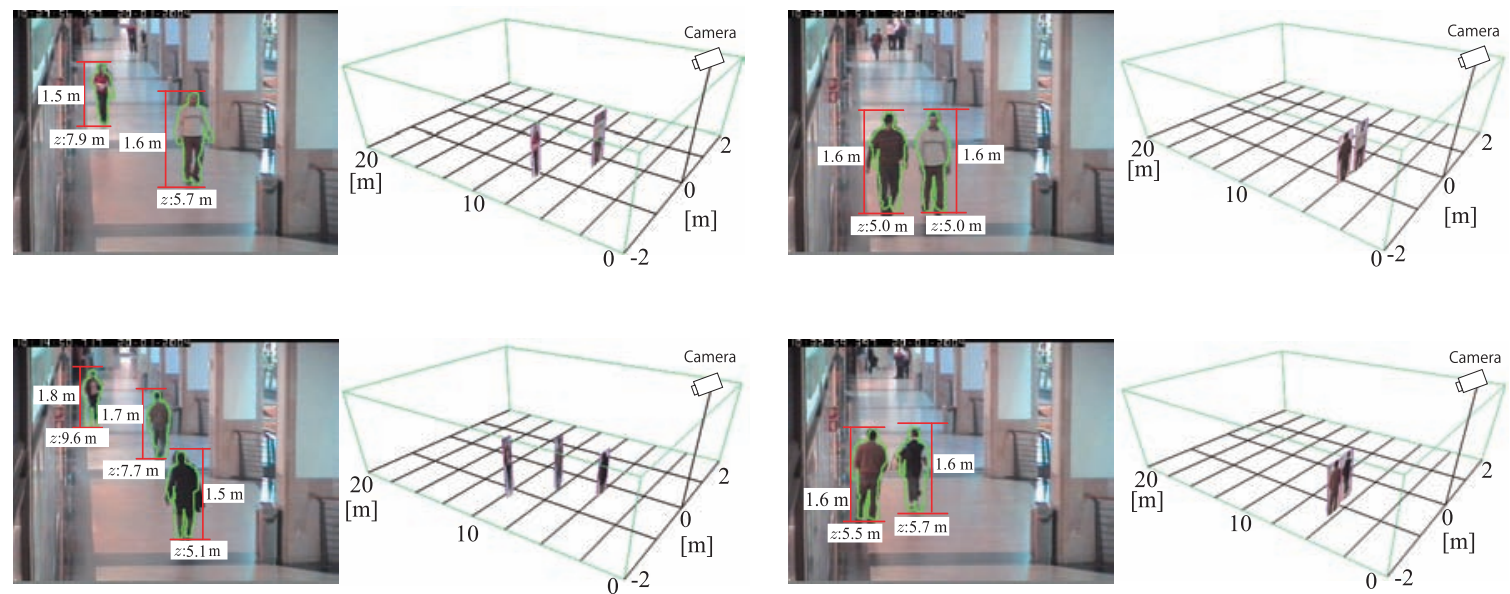

Fig. 15. Estimated results of 3D positions 2(CAVIAR dataset $\left.2^{(12)}\right) y_{c}=360.03[\mathrm{~cm}], v_{0}=1.17, \theta=27.5[\mathrm{deg}]$ 
ける物体の 3 次元位置推定が可能となり，評価実験により

その有効性を確認した。

今後は推定した物体の 3 次元位置情報を用いた高精度な 人の追跡を行う予定である。

(平成 22 年 6 月 21 日受付, 平成 22 年 11 月 26 日再受付)

\section{文献}

(1) N. Dalal and B. Triggs: "Histograms of Oriented Gradients for Human Detection", IEEE Computer Vision and Pattern Recognition, Vol.1, pp.886893 (2005)

(2) B. Wu and R. Nevatia: "Detection and Tracking of Multiple, Partially Occluded Humans by Bayesian Combination of Edgelet based Part Detectors", International Journal of Computer Vision, Vol.75, No.2, pp.247-226 (2007)

（3）小川雄三・藤吉弘亘：「実空間に対応した Master-Slaving による追尾 カメラシステム」, 第 9 回画像センシングシンポジウム (2003-6)

(4) R.Y. Tsai: "A Versatile Camera Calibration Technique for High-Accuracy 3D Machine Vision Metrology Using Off-the-Shelf TV Cameras and Lenses", IEEE Journal of Robotics and Automation, Vol.RA-3, No.4, pp.323-344 (1999)

( 5 ) F. Lv, T. Zhao, and R. Nevatia: "Camera calibration from video of a walking human", IEEE Trans. Pattern Analysis and Machine Intelligence, Vol.28, No.9, pp.1513-1518 (2006-9)

(6) D. Hoiem, A.A. Efros, and M. Hebert: "Putting Objects in Perspective", International Journal of Computer Vision, Vol.80, No.1 (2008)

（7）村井陽介・藤吉弘亘：「弱識別器の応答に基づく類似シルエット画 像選択による Chamfer Matching を用いた人領域のセグメンテーショ ン」,第 12 回画像の認識・理解シンポジウム (2009)

(8) R.E. Schapire and Y. Singer: "Improved Boosting Algorithms Using Confidence-rated Predictions", Machine Learning, No.37, pp.297-336 (1999)

(9) D.M. Gavrila: "Multi-feature Hierarchical Template Matching Using Distance Transforms", IEEE International Conference on Pattern Recognition, pp.439-444 (1998)
（10）平成 20 年度体力 - 運動能力調査調査結果統計表：文部科学省, http://www.mext.go.jp/b_menu/houdou/21/10/attach/1285568.htm

11) M. Fischer and R. Bolles: "Randam sample consensus: A paradigm for model fitting with applications to image analysis and automated cartography", Communications of the ACM 24, pp.381-385 (1981)

(12) http://homepages.inf.ed.ac.uk/rbf/CAVIARDATA1/

安 藤 寛 哲 (非会員) 2009 年中部大学工学情報卒業。同年

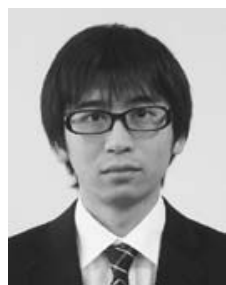
より同修士課程に在籍。画像処理，パターン認識 に関する研究に従事。電子情報通信学会会員。

藤 吉 弘 亘 (正員) 1997 年中部大学大学院博士後期課程修

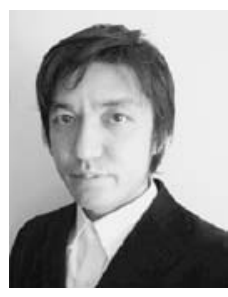
了。1997２000 年米カーネギーメロン大学ロボッ 卜工学研究所 Postdoctoral Fellow。2000 年中部大 学講師, 2004 年同大准教授を経て 2010 年より同 大教授。2005２006 年米カーネギーメロン大学 ロボット工学研究所客員研究員。工博。計算機視 覚, 動画像処理, パターン認識・理解の研究に従 事。2005 年度ロボカップ研究賞。2009 年度情報 処理学会論文誌コンピュータビジョンとイメージメディア優秀論文賞, 2009 年度山下記念研究賞。情報処理学会, 電子情報通信学会, IEEE 各会員。 